\title{
IMPACT OF COMPENSATION AND CAREER DEVELOPMENT ON JOB SATISFACTION AND EMPLOYEES PERFORMANCE
}

\author{
Oseanita Winda*, Utami Hamidah Nayati, Prasetya Arik \\ Department of Business Administration, Faculty of Administrative Science, \\ University of Brawijaya, Indonesia \\ *E-mail: windaocean@yahoo.com
}

\begin{abstract}
Compensation is appreciation which is given to employees by company related to work ability, time and the given energy. A company would want qualified employees whose qualities increase every time. There are many ways to be done by the company to increase job satisfaction and employee performances, among them are the provision of compensation and career development for its employees. Compensation is the goal of employees to work, so the compensation gift in accordance with government rules and company policy is expected to improve productivity and profitability, while individual career development which is supported by the company will expand the scope of knowledge, the increase of capability and the employee confidence. This research is done to know how far compensation is investigated, in this case there are direct and indirect financial compensation and also career development which training program is included, promotion and assessment which influence to job satisfaction which focus on the work itself, supervision and work partner, and also is linked to employee performance with work quantity indicator, work quality, time accuracy, team work and presence in the workplace. It will be known whether adequate compensation received by employee and application in career development will influence job satisfaction and employee performance. This research is explanatory research. The sample of this study was 74 respondents. The data were analyzed by using Path Analysis. The findings of this study showed Compensation and Career Development had a significant effect towards Job Satisfaction, Compensation and Career Development had a significant effect towards Employee Performance. Furthermore, Job Satisfaction had a significant effect towards Employee Performance.
\end{abstract}

\section{KEY WORDS}

Compensation, career development, job satisfaction, employee performance.

There are some companies which develop well in all sectors, the development demands the readiness of human resources to adapt with development today. The company is demanded to be perceptive in addressing the development, one of the company readiness can be performed by managing company resource. The quality of human resource is determined by how far human resource system can support and satisfy the desire of company and employees. Dessler (2010), that human resource management is policy and practice which is needed by human resource which cover recruitment, selection, training, reward and appraisal. It can be concluded that human resource factor has main role in a company because it is an important asset in achievement of objectives. Mondy (2008), that compensation is the total of rewards received by employees as the replacement services done by them. The amount of compensation received by employees reflects position, status and the level of fulfillment enjoyed by employees. The more compensation the employees receive, the higher the positions are. The better status they have, the more needs they can enjoy. It will influence to job satisfaction which becomes better and so the performance (Suryati, 2011).

Neog and Barua (2014), that salaries are the most important factor to influence the employees job satisfaction. Besides getting the salaries, the employees also get incentive of overtime, bonus, and reward especially for the best employees in every month. They are given to increase employee job satisfaction. It proves that compensation has the important 
role in employee job satisfaction. Besides the fair compensation, the most important to pay attention by the company and to be desired by most of the employees is the guarantee in career development for the employees. Career development is really needed by private companies and Government Company as career development orients to the future challenge in facing the competitor. Career development has a future existence which depends on human resource, so the company must perform career coaching with a plan to the employees, sustainable and integrated with the other activities of human resource. The fair compensation realization and career development done by the company will be able to increase job satisfaction. If it increases, it will influence all employee performance. Armstrong and Baron in Wibowo (2011) that employee performance is the result of work action which has strong correlation with strategic organization goals, customer satisfaction and gives economic contribution.

\section{LITERATURE REVIEW}

Compensation. Wibowo (2011), compensation is contra achievement to the usage of energy and service given by employees. Mainly, the objective of compensation is to get qualified human resource, maintain the existence of employees, guarantee the justness, appreciate the desire of willingness, control the cost, obey the law regulation, increase the administration efficiency and it is easy to be understood.

Kinds of compensation, Mondy (2008):

- Financial Compensation - direct financial compensation consists of pay, salary, commission and bonus. Indirect financial compensation (allowance) is all financial reward which is not included in direct compensation. They are many kinds of indirect rewards received by employees in this kind of compensation.

- Non financial Compensation - non financial Compensation is a satisfaction received by someone related to his work, psychological environment and the office where he works. Its aspect consists of psychological factors and the office.

Career Development. Rivai and Sagala (2010), that career development is the process of the increase of individual work ability which is achieved to attain the desired career. Rivai (2008) that the objectives of career development are:

1. To increase the employees who can be promoted. Career plan can help the supplying of internal employees talents, which can be promoted to fulfil the job vacancy caused by pension, resignation and the growth of employees.

2. To decrease replacement. The companies increase concern and employee agreement of their loyalty to the company and decrease the level of employee resignation.

3. To select employee potential. Career plans support the employees to be selective in using their abilities as they have special career objectives.

4. To continue further personal growth. Career plans support the employees to grow and make progress.

5. To satisfy the employee needs. It there is a chance for employees to grow, make progress and individual needs of dignity are fulfilled caused employees to be easy to be satisfied.

There are some aspects related to employee career development are performance, exposure, network, resignation, organization loyalty, supervisor and sponsor, subordinates who have a key role, a chance to make progress and international experience. While some aspects which have important roles in career development which are supported by human resource department are the role of leader in career development and feedback role to career development. There are some career development program which can be done by organization or company are training and education, arrangement compensation system, promotion program, rotation, demotion, performance evaluation, group learning program, mentoring program, scholarship program and commitment to work for the company.

Job Satisfaction. Robbins (2001), the term job satisfaction refers to the general attitude of an individual towards his job, if the employees feel satisfied with their jobs, they will bring a 
positive attitude to their jobs, a person with high job satisfaction holds positive attitude towards the job and one who is dissatisfied with it will have negative attitudes towards it.

Smith, Kendall dan Hulin in Luthans (2006), factors that drive job satisfaction are works that mentally challenging, because employees prefer to jobs that give them the opportunity to use their skills and abilities, proper rewards, because the employees want the wage system and promotion policy which is fair and in line with their expectations, a conducive working environment for the employees concern about the working environment both for personal comfort and to ease to do the task, partners who support, suitability of personality to the job, because the employees should have the talent and the right skills to get the demands of their jobs, opportunity promotion within the company and the supervision of the supervisor to pay attention to the interest and attention to workers.

Employee Performance. Armstrong and Baron in Wibowo (2011), performance is the result of work that has a strong relationship with the organization strategic objectives, customer satisfaction and contribute to the economy. The factors that affect the performance can be concluded (1) the personal factor can be indicated by the level of skill of their competence, motivation, and commitment of individuals, (2) leader factor gives motivation, guidance, and support, (3) team factors, support given by co-workers, (4) working system and facility factors provided by the organization, (5) environmental internal organization factors, organization support where the employees work, (6) environmental external organization factors are condition, events, or situation that occur outside organizations that affect employee performance.

\section{METHODS OF RESEARCH}

The study used a quantitative research methods, with the variables: Compensation, Career Development, job satisfaction and Employee Performance. This research can be categorized as a causality research. The location of this research at Satate-Owned Enterprises (State Electricity Company) Malang. Sampling technique used in this research is to use saturation sampling. According Sugiyono (2008) that is saturation sampling technique when all members of the population used as a sample. Other terms of the saturation sample is census, where all members of the population sampled. Saturation sampling is used because the population is relatively small. The samples was 74 respondents. This study used a questionnaire distributed to respondents. To examine the relationship between these variables, inferential analysis was used in the form of Path Analysis. The research framework is presented in Figure 1.

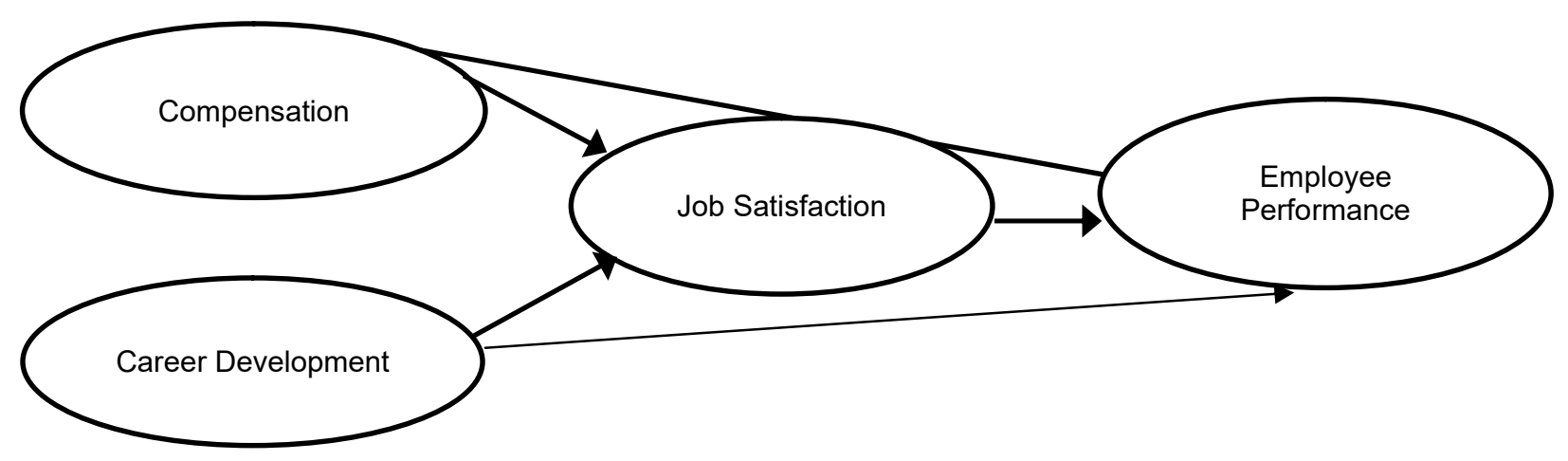

Figure 1 - Research Framework

Hypotheses:

$\mathrm{H}_{1}$ : Compensation and Job Satisfaction have a significant correlation.

$\mathrm{H}_{2}$ : Compensation and Employee Performance have a significant correlation.

$\mathrm{H}_{3}$ : Career Development and Job Satisfaction have a significant correlation.

$\mathrm{H}_{4}$ : Career Development and Employee Performance have a significant correlation.

$\mathrm{H}_{5}$ : Job Satisfaction and Employee Performance have a significant correlation. 


\section{RESULTS AND DISCUSSION}

The test results linearity path analysis of the first model showed that between independent variables and dependent variable has significant test of linearity smaller than 0.05 , which means that the relationship between independent and dependent variables is linear, so it can be concluded that on a path analysis on the first model, assuming linearity has been fulfilled.

In the second model of path analysis, it shows that between independent variables and the dependent variable there is a significant test of linearity smaller than 0.05 , which means that the relationship between independent and dependent variables is linear, so it can be concluded that on the model path analysis II, assuming linearity has been fulfilled. Overall, assuming path analysis has been fulfilled, so that the data in this study were analyzed by using path analysis feasible. The following is linearity testing table:

Table 1 - Linearity Test Results

\begin{tabular}{|c|c|c|c|c|c|}
\hline Path Model & Independent Variable & Dependent Variable & $\mathrm{F}$ & Sig. & Result \\
\hline \multirow{2}{*}{ Model I } & $\mathrm{X}_{1}$ & $\mathrm{Y}_{1}$ & 3354,555 & 0,000 & Linier \\
\cline { 2 - 6 } & $\mathrm{X}_{2}$ & $\mathrm{Y}_{1}$ & 94,074 & 0,000 & Linier \\
\hline \multirow{3}{*}{ Model II } & $\mathrm{X}_{1}$ & $\mathrm{Y}_{2}$ & 2867,372 & 0,000 & Linier \\
\cline { 2 - 6 } & $\mathrm{X}_{2}$ & $\mathrm{Y}_{2}$ & 123,108 & 0,000 & Linier \\
\cline { 2 - 6 } & $\mathrm{Y}_{1}$ & $\mathrm{Y}_{2}$ & 2589,207 & 0,000 & Linier \\
\hline
\end{tabular}

Notes: Compensation $\left(X_{1}\right)$, Career Development $\left(X_{2}\right)$, Job Satisfaction $\left(Y_{1}\right)$, Employee Performance $\left(Y_{2}\right)$.

The test result (Table 2 ) shows that the path coefficient variable Compensation $\left(X_{1}\right)$ to Job Satisfaction $\left(Y_{1}\right)$ of 0.912 with probability ( $p$-value) of 0.000 , which means a significant effect. Compensation $\left(\mathrm{X}_{1}\right)$ to Employee Performance $\left(\mathrm{Y}_{2}\right)$ of 0.529 with probability ( $\mathrm{p}$-value) of 0.000 , which means a significant effect. Career Development $\left(X_{2}\right)$ to Job Satisfaction $\left(Y_{1}\right)$ of 0.100 with probability ( $p$-value) of 0.001 , which means a significant effect. Career Development $\left(\mathrm{X}_{2}\right)$ to Employee Performance $\left(\mathrm{Y}_{2}\right)$ of 0.160 with probability ( $p$-value) of 0.000 , which means a significant effect. And the last, Job Satisfaction $\left(Y_{1}\right)$ to Employee Performance $\left(Y_{2}\right)$ of 0.343 with probability ( $p$-value) of 0.001 , which means a significant effect.

Table 2 - Output of Path Analysis

\begin{tabular}{|l|l|l|l|}
\hline The Direct Effect & Path Coefficient & Significances (p-value) & \\
\hline$X_{1} \rightarrow Y_{1}$ & 0,912 & 0,000 & Significant \\
\hline$X_{1} \rightarrow Y_{2}$ & 0,529 & 0,000 & Significant \\
\hline$X_{2} \rightarrow Y_{1}$ & 0,100 & 0,001 & Significant \\
\hline$X_{2} \rightarrow Y_{2}$ & 0,160 & 0,000 & Significant \\
\hline$Y_{1} \rightarrow Y_{2}$ & 0,343 & 0,001 & Significant \\
\hline
\end{tabular}

Notes: Compensation $\left(X_{1}\right)$, Career Development $\left(X_{2}\right)$, Job Satisfaction $\left(Y_{1}\right)$, Employee Performance $\left(Y_{2}\right)$.

Hypothesis 1 stated that Compensation (X1) has a significant effect on job satisfaction (Y1). The results of regression analysis of Compensation (X1) on Job Satisfaction (Y1) which the results showed a significant probability value ( $p$-value) of 0.000 with the path coefficients (beta) of 0.912 and a significance value less than 0.05 . It can be concluded that the data support the hypothesis $\mathrm{H} 1$ where there is significant influence between Compensation (X1) on Job Satisfaction (Y1). In accordance with that proposed by Schuler and Jackson (1996) that the influence of employee satisfaction on compensation is determined by equity compensation, the level of compensation, and practice administration compensation. The findings of this study support previous research conducted by Neog and Barua (2014), proving that the compensation gives direct effect on employee satisfaction.

Hypothesis 2 stated that compensation (X1) significantly influence the employee performance (Y2) with significant value 0,000 smaller than $\alpha(0.05)$. This means that the higher the compensation given by the company will encourage to produce a good and high 
employee performance. On the other hand compensation gives significant effect on employee performance with influence value of 0.626 or $62.6 \%$. The findings of this study support previous research conducted by Thaief, et al (2015) which proves that the compensation has a significant influence on employee performance. The results of this study also support research by Hameed, et al (2013) to a bank employees in Pakistan, providing that compensation has significant influence on employee performance. Sultana, et al (2012) in his research found that the compensation in this case is that the salary has a positive and significant relationship on performance. This means that salaries can provide Income assurance for employees and performance can be improved by creating healthy competition among salaried employees.

Hypothesis 3 stated that career development (X2) significantly influence to job satisfaction (Y1) with significant value 0,001 smaller than $\alpha(0.05)$. This means that the higher the career development given by the company will produce both good and higher job satisfaction. Career development significantly effects on job satisfaction with the value influence 0,100 . The findings of this study support previous research conducted by Shujaat, et al (2013) who examined the private bank employees in Karachi. This study found that there is a positive relationship between career development and job satisfaction of employees in the banking sector.

Hypothesis 4 stated that career development (X2) significantly influence employee performance (Y2) with significant value 0,000 smaller than $\alpha(0.05)$. This means that the higher the career development provided by the company will produce good and high employee performance. Career development significantly effects on the employee performance with influence value of 0,138 or $13.8 \%$. The findings of this study support previous research conducted by Wibowo (2006). The analysis showed that the career development has significant and positive effect on the employee performance. The results of this study indicate that companies need to manage their careers and development well so that employee productivity is maintained and able to encourage employees always to do the best and avoid the work frustration which results in commitment employee reduction to remain in the organization.

Hypothesis 5 stated that job satisfaction (Y1) significantly influence on employee performance $(Y 2)$ with significant value 0,001 smaller than $\alpha(0.05)$. This means that the higher the job satisfaction perceived by employee will produce a good and high employee performance. Job satisfaction has a significant effect on the employee performance with influence value of 0.343 or $34.4 \%$. The findings of this study support previous research conducted by Qureshi et al. (2011) which examined employees who worked in different sectors of the organizations in Rawalpindi in Pakistan. The result is a variable of job satisfaction positively and significantly effects with employee performance variables. This is similar to the research conducted by Funmilola, et al (2013) on the Small and Medium Enterprises in Ibadan metropolis, Nigeria. The results showed that job satisfaction significantly influence on employee performance.

\section{CONCLUSION}

Human resource management is planning, organizing, directing and controlling of procurement, development, compensation, integration, maintenance and dismissal of employees for the purpose of realization of objectives of the company, individuals, employees and the community. Compensation is appreciation achievement of all work abilities, time and effort provided by the employee to the company in which with direct compensation indicator and indirect compensation have been fulfilled in accordance with the expectations of respondents. It was found that in career development variables, indicators of training, promotion program and assessment program had been in line with expectations of respondents. It was also found that in job satisfaction variables, indicators of the work itself, supervision and co-workers had been in line with expectations of respondents. It has been found that in the variable employee performance, the indicator quantity of work, quality of 
work, timeliness, collaboration with colleagues and presence in the workplace have been in line with expectations of respondents.

There is a significant effect of compensation on employee job satisfaction of PT. PLN (Persero) Malang area. It can be concluded that the high or low levels of compensation will have an impact on job satisfaction. The higher compensation would encourage better employee satisfaction, while the low compensation would reduce employee job satisfaction. There is a significant effect of compensation on employee performance of PT. PLN (Persero) Malang area. This means that better compensation given will be directly in proportional to the increasing of the employee performance. There is a significant influence of career development on employee job satisfaction of PT. PLN (Persero) Malang area. It can be concluded that the better career development for employees will increase employee job satisfaction and vice versa, the decrease in employee career development practices will reduce employee job satisfaction. There is a significant influence of career development on employee performance PT. PLN (Persero) Malang area. It can be concluded that the growing of the practice of employee career development also supports employee performance improvement. It was found that there was a significant effect of job satisfaction on the performance of employees of PT. PLN (Persero) Malang area. It can be concluded that good job satisfaction of the employees would be able to improve employee performance and conversely, the decline in employee job satisfaction helped reduce employee performance.

\section{REFERENCES}

1. Dessler, Gary. 2010. Manajemen Sumber Daya Manusia, Jilid I. Prehallindo. Jakarta.

2. Funmilola, Oyebamiji Florence, Kareem Thompson Sola, Ayeni Gabriel Olusola. 2013. "Impact of Job Satisfaction Dimensions on Job Performance in a Small and Medium Enterprise in Ibadan, South Western, Nigeria". Interdisciplinary Journal Of Contemporary Research In Business. Vol. 4. No.11. pp. 509-521.

3. Hameed, Abdul, Muhammad Ramzan, Hafiz M. Kashif Zubair, Ghazanfar Ali, Muhammad Arslan. 2014. "Impact of Compensation on Employee Performance (Empirical Evidence from Banking Sector of Pakistan)". International Journal of Business and Social Science. Vol.5. No.2; February. pp. 302-309.

4. Luthans, Fred. 2006. Perilaku Organisasi, Alih Bahasa: V.A Yuwono, Edisi Bahasa Indonesia. Penerbit Andi. Yogyakarta.

5. Mondy, R. Wayne. 2008. Manajemen Sumber Daya Manusia, Edisi 10, Jilid I. Erlangga. Jakarta.

6. Neog, Bidyut Bijoya dan Dr. Mukulesh Barua. 2014. " Factors Influencing Employee's Job Satisfaction: An Empirical Study among Employees of Automobile Service Workshops in Assam." The Standard International Journals Transactions on Industrial, Financial \& Business Management (IFBM) Vol. 2, No. 7. pp. 305-316.

7. Qureshi, Javeria Ashfaq, Khansa Hayat, Mehwish Ali, Nosheen Sarwat. 2011. "Impact of Job Satisfaction and Organizational Commitment on Employee Performance, Evidence from Pakistan". Interdisciplinary Journal Of Contemporary Research In Business. Vol.3, No.4. pp. 642-657.

8. Rivai, Veithzal, Ella Jauvani Sagala. 2010. Manajemen Sumber Daya Manusia untuk Perusahaan dari Teori ke Praktik, Edisi 2. Rajawali Pers. Jakarta.

9. Rivai, Veithzal. 2008. Manajemen Sumber Daya Manusia untuk Perusahaan dari Teori ke Praktik. Raja Grafindo Persada. Jakarta.

10. Robbins, Stephen P. 2001. Perilaku Organisasi, Konsep, Kontroversi, Aplikasi, Alih Bahasa: Hadyana Pujaatmaka. Prehallindo. Jakarta.

11. Shujaat, Sobia, Saira Sana, Dr. Faisal Aftab, Ishtiaq Ahmed. 2013. "Impact of Career Development on Employee Satisfaction in Private Banking Sector Karachi". Journal of Management and Social Sciences.Vol. 9, No.2. pp. 01-08.

12. Sugiyono. 2008. Metode Penelitian Bisnis. Alfabeta. Bandung. 
13. Sultana, Afshan, Sobia Irum, Kamran Ahmed, Nasir Mehmood. 2012. "Impact Of Training On Employee Performance: A Study Of Telecommunication Sector In Pakistan", Interdisciplinary Journal Of Contemporary Research In Business Vol.4, No.6. pp.646-661.

14. Suryati. 2011. "Pengaruh Kompensasi, Motivasi Kerja dan Kepuasan Kerja terhadap Kinerja Karyawan". Tesis Program Magister IImu Administrasi Bisnis, Fakultas IImu Administrasi, Universitas Brawijaya Malang.

15. Thaief, Ilham, Aris Baharuddin, Priyono, Mohamad Syafi'i Idrus. 2015. "Effect of Training, Compensation and Work Discipline against Employee Job Performance (Studies in the Office of PT. PLN (Persero) Service Area and Network Malang)." Review of European Studies Vol. 7, No. 11. pp. 23-33.

16. Wibowo, Felicia Dewi. 2006. "Analisis Pengaruh Peran Kepemimpinan dan Pengembangan Karir terhadap Komitmen Organisasi dalam Meningkatkan Kinerja Karyawan." Tesis Program Pascasarjana. Magister Manajemen, Universitas Diponegoro. Semarang.

17. Wibowo. 2011. Manajemen Kinerja. Rajawali Pers. Jakarta. 